\title{
Learning Factory Concept and Development at Faculty of Industrial Management, Universiti Malaysia Pahang
}

\section{Mohd Ghazali Maarof, Gusman Nawanir, and Muhammad Fakhrul Yusuf}

Faculty of Industrial Management, Universiti Malaysia Pahang, Lebuhraya Tun Razak, 26300 Gambang, Pahang, Malaysia

\section{Abstract}

One of the key resources for the organization to sustain in the competitive business world is the employee's competencies. Current business environment requires employees who are competent to adapt to ever-changing the business environment as a result of globalization and changes in customer's requirement. The current teaching and training methods used in the universities is lacking a continuous delivery of competencies, especially in manufacturing education. One of the approaches that are becoming popular in developing student's competencies is through the application of

Corresponding Author: Mohd Ghazali Maarof mohdghazali@ump.edu.my

Received: 5 August 2019 Accepted: 14 August 2019 Published: 18 August 2019

Publishing services provided by Knowledge E

(c) Mohd Ghazali Maarof et al. This article is distributed under the terms of the Creative

Commons Attribution License, which permits unrestricted use and redistribution provided that the original author and source are credited.

Selection and Peer-review unde the responsibility of the FGIC2019 Conference Committee.

\section{G OPEN ACCESS} the learning factory concept. A learning factory represents a simulation of a real factory environment where students can gain hands-on the learning experience by conducting various projects. This paper will, therefore, present the process of setting up a learning factory and discuss how the learning factory can be used to support the teaching and learning process in a public technical university. This study was performed at the Faculty of Industrial Management, Universiti Malaysia Pahang. The purpose of the development of such a learning factory is to enable the students to attained hands-on experience on the concepts they have learned during class lecture and see how it can be applied in the real world.

Keywords: learning factory, experiential learning, lean management, transformation, globalization.

\section{Introduction}

One of the key resources for firms to sustain in this competitive business environment is the employee's competency. This is due to the rapid changes in technological advancement, as a result of globalization and changing customer's demand. These changes have significantly impacted the nature of how to work in the industry. For instance, the manufacturing industry landscape, which used to be predominantly characterized by manual labor operation, has gradually transformed into more automated processes over the past several decades. This transformation of manufacturing technology has demanded a more effective competency development approaches to help firms acquire the required 
human capital needed to work in the industry. University students have been trained with the knowledge to help them ready to face the challenges in the industry. This has allowed the graduates to apply the knowledge they have gained in the university to solve the industrial issues is very crucial. However, many of the current teaching and training methods used in the universities lack a continuous delivery of competencies especially in the manufacturing education (Tether, B., Mina, A., Consoli, D., Gagliardi, D., 2005). Cachay J, Wennemer J, Abele E, Tenberg R, (2012) in their studies have found that many of the universities are still using the traditional classroom method such as pictures, videos, and case study to teach students about the manufacturing environment. The students have very little exposed when it comes to the hands-on learning experience since many of the activities are done in the classroom. However, for students to be a capable and competent practitioner, an effective knowledge transfer method which can expose the students to the current and future competencies is required. However, to prepare the students with these kind of skills, the universities will need to match the education system with the competencies that are required by the industry (Abele, E., Metternicha, J., Tischa, M., Chryssolourisb, G., Sihnc,W., ElMaraghyd, H., Hummele, V., Ranz, F., 2015). One of the approaches that are becoming popular in the development of student's competencies, especially in universities, is through the application of the learning factory concept. Therefore, the objectives of this study are to understand the following issues:

1. The setting up of a learning factory in a public technical university in Malaysia

2. How can the learning factory be used to support the teaching and learning process in a public technical university in Malaysia?

\section{Literature Review}

The economic growth, especially during this globalization era, is challenged by a lack of skilled and qualified workforce to work in the industry. There is a mismatched between the qualification of the available workforce and the changes that had happened in the industry. Universities should, therefore, play a bigger role to close these gaps so that the students that they produce will be ready for the job market (Khalid, N., Abd Hamid, N.A., Sailin, R., Othman, N., Awang, A.H., Mat Nor, M.F., 2014). However, many young graduates lack important competencies such as creative skill as well as communications and teamwork (Matt, D. T., Rauch, E., \& Dallasega, P., 2014). The students might have been trained in the right technical knowledge, however, majority of them does not 
possess the soft skills required by the industry (Nazron, M.A., Lim, B. \& Janice L.H., 2017) such as lack of decision making and work planning skills as perceived by the Malaysian employers (Agus, A., Awang, A.H., Yussof, I. \& Mohamed Makhbul, K.M., 2011). This poor soft skill among university graduates has been identified to be one of the key factors that have affected the graduate employability in Malaysia (Hanapi, Z., \& Nordin, M. S., 2014). Furthermore, the students were also found to be lacked practical experience especially those involving the application of the technical know-how (Khalid, N., Hamid, N. A. A., Sailin, R., Othman, N., Awang, A. H., \& Nor, M. F. M., 2014). According to a study by Abele, E., Metternich, J., \& Tisch, M. (2018), learning factories can be used to enhance student's technical knowledge as well as to develop social and personal competencies such as team building, leadership, and communication. However, a comprehensive scientific study on how learning factory can be used to address those challenges is still lacking. There are various definitions given in defining the term "Learning Factory." However, within the CIRP Collaborative Working Group (CWG), a learning factory should have the following key characteristics (Abele et al., 2015):

- Purpose: teaching and training and/or research

- Process: that are authentic + multi-stage + technical and organizational

- Setting: that is changeable + real or virtual

- Product: physical or service

- Didactics concept: based on formal and informal learning enabled by own actions of the trainees in an on-site or remote learning approach.

- Operating Model: sustainable plan allows the ongoing operation (desired)

Declining product lifecycle, a rising number of product variants, globalization and an increased frequency of job rotation has required the need to increase competency building to ensure the sustained growth of the manufacturing industry (Abele, 2016). Thus, a new shift is needed both in education content and didactical approaches to respond to the new challenges in the manufacturing industry. According to Chryssolouris, G., Mavrikios, D., \& Mourtzis, D. (2013), a learning factory presents a promising approach towards a shift in the learning approach to increase competency building. The theory of Constructivism by Piaget, J. (1964) has had a significant impact on the way education has evolved. Piaget's Constructivism theory suggested that educators should allow ample space for the students to engage in concrete experiences and explore the world around them to develop their cognitive and social skills. Through the process of accommodating and assimilating their internal representation of the world with their 
real experience, the students will learn to construct new knowledge. This theory defines the role of the instructors is to support the learner by providing guidelines and creates the environment for the learners to arrive at his or her conclusions. Thus, the learning environment should also be designed in such a way it will support and challenge the learner's thinking in becoming an effective thinker. Learners need to be constantly challenged with tasks that require skills and knowledge that is beyond their current level of mastery. Learners will make their inferences or discoveries without someone need to told them what will happen next. The learning experience should be open and free enough to allow the learners to discover, enjoy, interact, and arrive at their conclusions.

\section{Methodology}

The primary aim of this research is to evolve a didactic concept in the areas of Supply Chain and Operation Management using a learning factory approach. The aim is to prepare the students with the competencies that are required by the Industry. This study was performed at the Faculty of Industrial Management, Universiti Malaysia Pahang. The Lean Management subject has been chosen to be the pilot study subject for this learning factory project. A learning factory represent a simulation of a real factory through specialized equipment with a learning environment where students can gain hands-on learning experience by conducting various projects Veza, I., Gjeldum, N., Mladineo, M., Celar, S., Peko, I., Cotic, M.,... \& Stojkic, Z. (2017). This means that the processes and technologies available in the learning factory are characterized by a changeable multilink value chains which enable a direct approach to different phases of product lifecycle process as a way to simulate a reality-conform production environment (Jäger, A., Mayrhofer, W., Kuhlang, P., Matyas, K., Sihn, W., 2013)

\section{Results}

Realizing the needs for a hands-on activity to be embedded in the curriculum, the Faculty of Industrial Management, Universiti Malaysia Pahang has started a project to build a learning factory in 2016. The learning factory was later named as "FIM learning factory" which has started its operation in October 2017 after a year of planning, designing and constructing the factory. The initial size of the learning factory is 588-meter square and located in the Gambang campus. The learning factory consists of a receiving warehouse, an assembly line, a Quality Control section, an outgoing warehouse, and 
packing/logistic processes which simulate a continuous flow of a hand dryer assembly processes. The learning factory aims at introducing the Faculty of Industrial Management undergraduate's students about the broad spectrum of manufacturing supply chain and operation management processes from part receiving, material storage, assembly process, quality control, packing and delivery of good. Figure 1 shows the diversity of activities that take place in the learning factory.

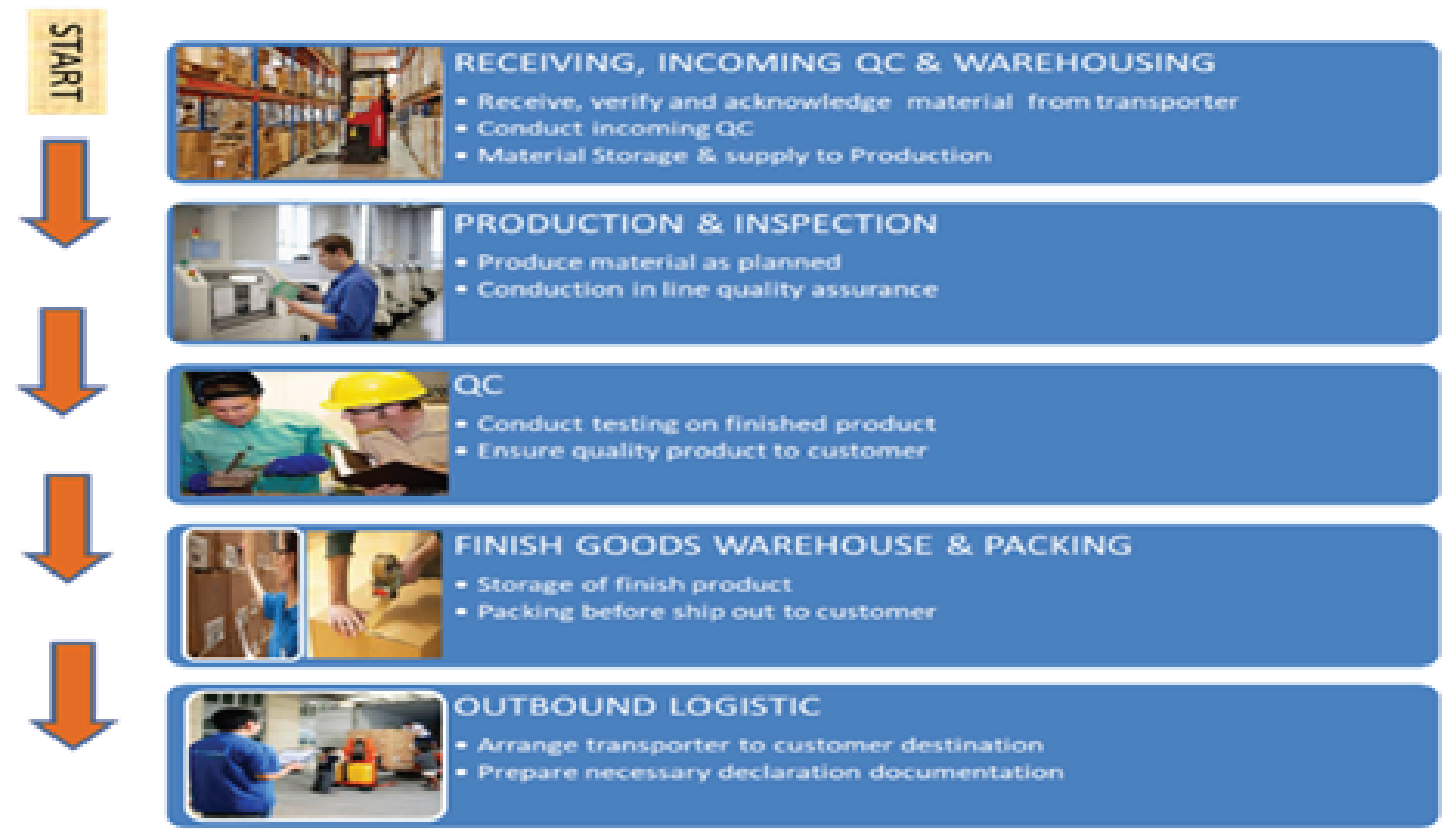

Figure 1: Supply Chain and Operation Management learning factory process flow.

One of the objectives of creating this learning factory is to create a simulated business environment where young students will have the opportunity to expose themselves and solve a real manufacturing problem. To prepare the students with the learning process, the assembly line was set-up based on the following criteria:

- Flexible production,

- Changeable, cellular system,

- Reconfigurable

Such criteria of a learning factory will allow the students to reconfigure the assembly process based on a task being assigned, such as continuous improvement and optimization study. Figure 2 shows photos of how the assembly line was set up

To expose the students with the concept of flexible production, changeable, cellular system, and reconfigurable production system, the following equipment was installed in the learning factory: A cellular changeable production system, changeable workstations, 


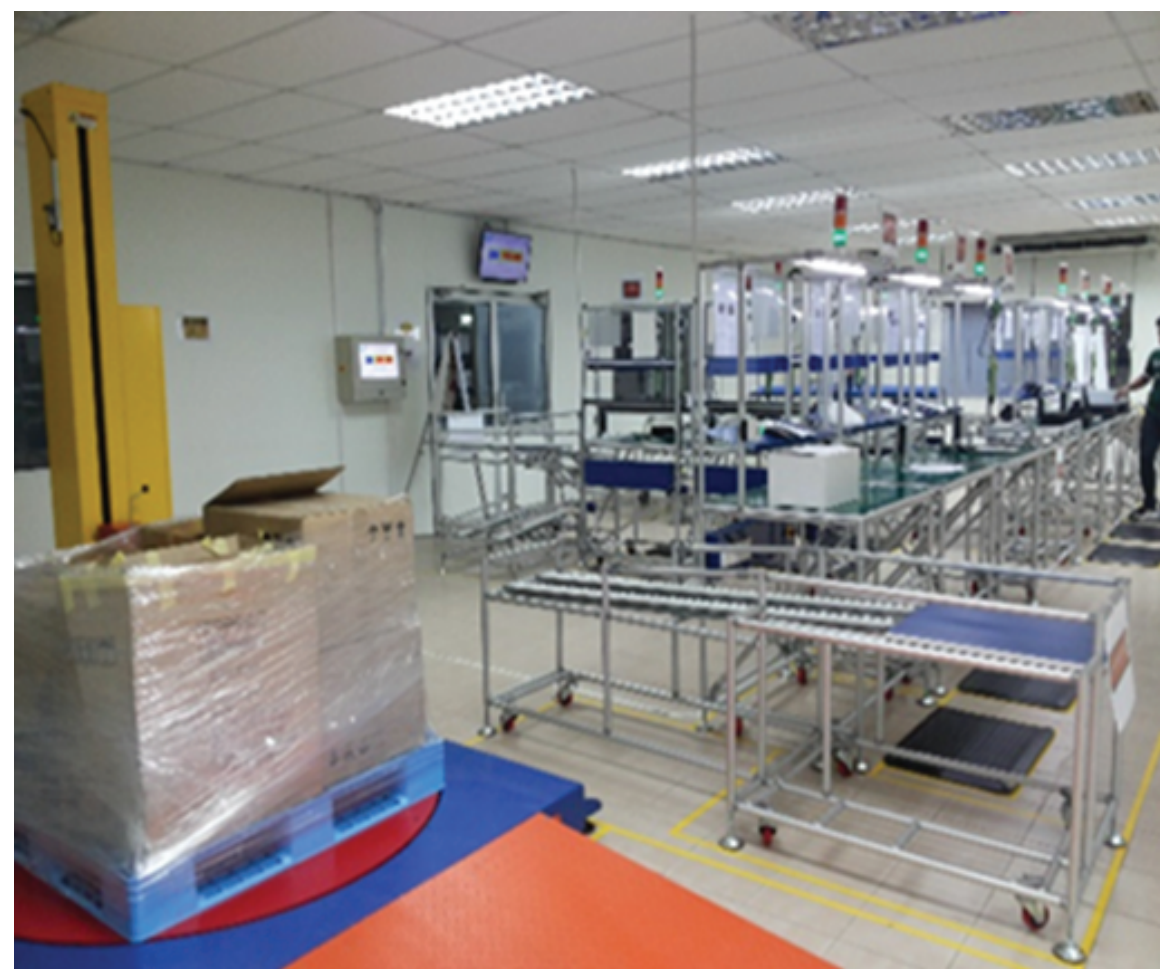

Figure 2: Photo of the Learning Factory Assembly Line.

and flexible overhead wiring system. Figure 3 shows various equipment installed in the learning factory
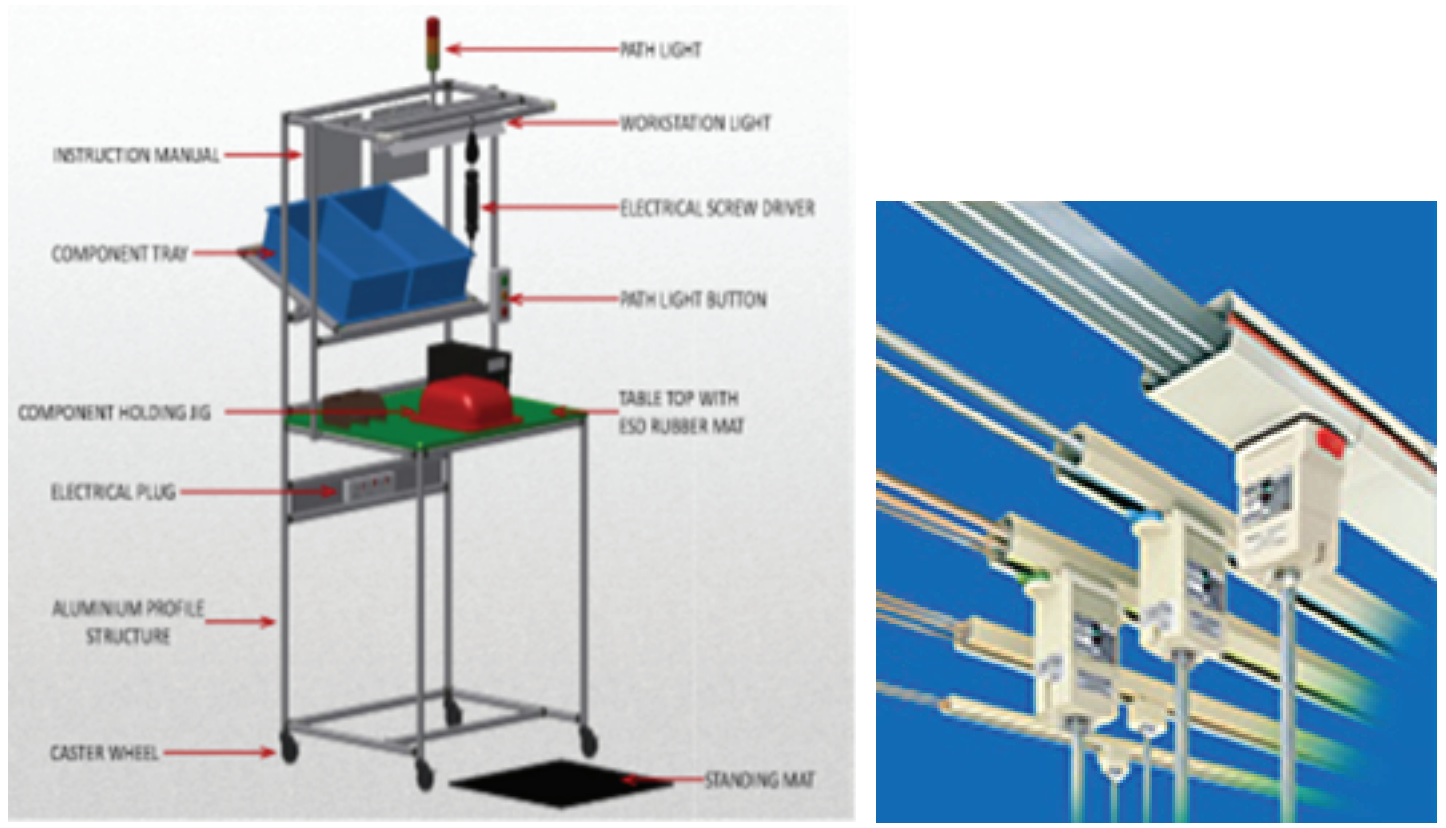

Figure 3: Various Equipment Installed in the Learning Factory.

The workstations were made of a highly flexible plug-in system of tabular standard aluminum profile frames. Through this concept, the workstation can be easily mounted 
or knocked down very quickly, thus, allowing changeability. Lockable wheels were installed to guarantees a high level of mobility to the workstation, especially when relay out is required. To illustrate the one-piece flow concepts, the workstations were arranged in a linear way next to one another with the sub-assembly process connected directly to the main assembly line.

The vision of the FIM learning factory is to create a place where the university and industry can share needs, expectation, and works on collaborative projects. The mission is to bring the real industry world into the classroom by providing practical hands-on experience to the university students and help transfer the latest research to the industry through a collaborative project. There are four objectives that have been identified:

- Students' competency development: To provide an experiential learning process for students based on real industry environment.

- Industry engagement: To work closely with industry partners in solving real industry problems

- Product Commercialization: To generate new income for the faculty/ university

- Innovative platform: To create a platform for students/researchers to develop innovative solutions/products

The idea to develop the learning factory started in September 2016. To create a hands-on learning process, an assembly line for hand dryer assembly process which comprises of both manual and semi-automated workstations has been proposed. After benchmarking a few related industries within the Malaysian, a design concept was agreed, and the construction of the learning factory begin in early 2017 and completed by September 2017. It was ready to be used in October 2017. Figure 4 shows the milestone of the learning factory establishment.

Lean management subject has been chosen as the pilot study for the learning factory project. Through the activities prepared in learning factory, the students have the chance to experience the whole supply chain process from parts receiving process until finish goods warehouse. Fifty-five different parts need to be assembled to complete one full product. Students were assigned to work on various lean management activities such as designing layout planning for the assembly process, develop a balanced assembly line, identify wastes in the lines, conduct kaizen activities and develop a pull system using Kanban. To help the students with the design, the faculty has provided the students with the solid work software to allow product development using 2D and 3D drawings models. A 3D printer was also available to enable the students to come out with product 


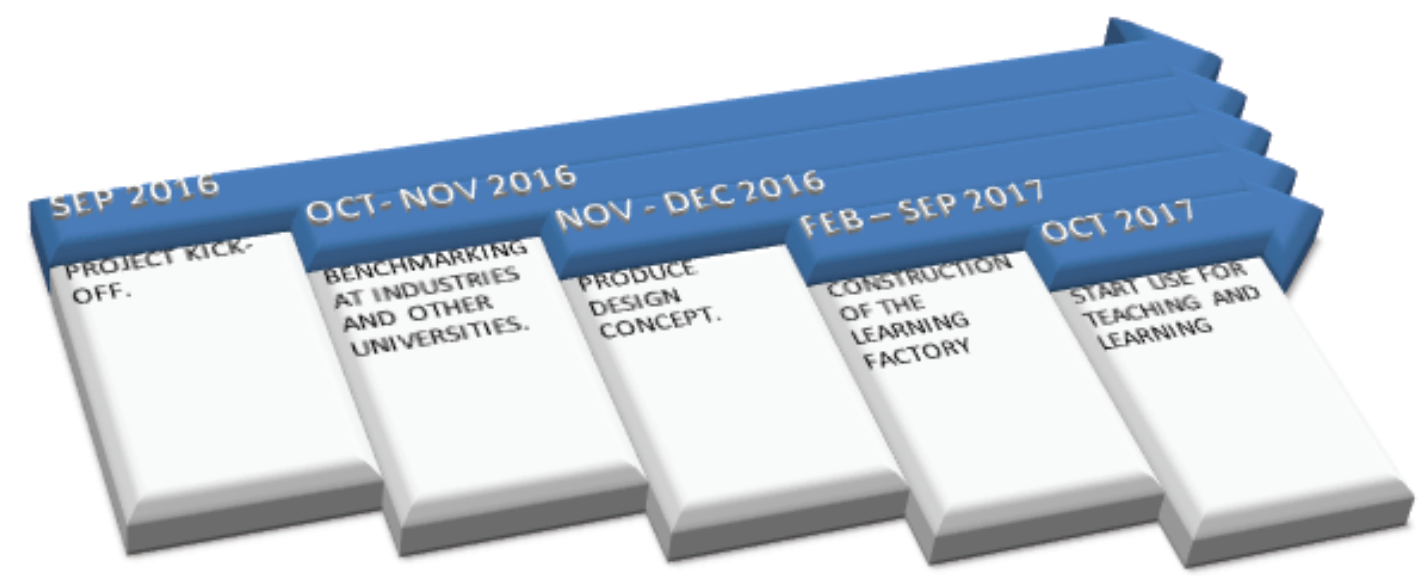

Figure 4: Milestone of the Learning Factory Establishment.

realization based on the design made using the solid work software. Figure 5 shows the framework used to conduct the activities in the learning factory

\section{Students learn the theoretical concept during class lecture}

Students go to the learning factory to experience the actual implementation.

Students carried out project based on assignment given in the learning factory

\section{Lecturer evaluate the result and give feedback to the students.}

Figure 5: Teaching and Learning Framework.

\section{Conclusion and Implications}

In this paper, the development of a supply chain and operation management learning factory at Faculty of Industrial Management, Universiti Malaysia Pahang has been explained. The purpose of the development of this learning factory is to enable students 
at the faculty of Industrial Management to attained hands-on experience to the concepts they have learned during a class lecture. By this way, the students can see how it can be applied in the real world through the use of a simulated factory called a learning factory. A framework on how the learning factory has been used in the curriculum has also been explained in this paper. Lean Management course has been selected to be in the pilot study. Future study should investigate more details about the impacts of the learning factory towards students learning experience.

\section{Acknowledgment}

We would like to thank Faculty of Industrial Management and FIM's Governance and Integrity Centre, Universiti Malaysia Pahang for the financial support by sponsoring this paper to be presented in the FGIC 2nd Conference on Governance and Integrity 2019.

\section{References}

[1] Abele, E., Metternich, J., Tisch, M., Chryssolouris, G., Sinn, W., ElMaraghy, H., \& Ranz, F. (2015). Learning factories for research, education, and training. Procedia CiRp, 32 , $1-6$.

[2] Abele, E. (2016). Learning factory. CIRP Encyclopedia of Production Engineering, 1-5.

[3] Abele, E., Metternich, J., \& Tisch, M. (2018). Learning Factories: Concepts, Guidelines, Best-Practice Examples. Springer.

[4] Agus, A., Awang, A. H., Yussof, I., \& Mohamed Makhbul, Z. K. (2011). The gap analysis of graduate employees' work skills in Malaysia. Proceedings of Business and Information, 8, 15.

[5] Cachay, J., Wennemer, J., Abele, E., \& Tenberg, R. (2012). Study on action-oriented learning with a Learning Factory approach. Procedia-Social and Behavioral Sciences, $55,1144-1153$.

[6] Chryssolouris, G., Mavrikios, D., \& Mourtzis, D. (2013). Manufacturing systems: skills \& competencies for the future. Procedia CIRp, 7, 17-24.

[7] Hanapi, Z., \& Nordin, M. S. (2014). Unemployment among Malaysia graduates: Graduates' attributes, lecturers' competency and quality of education. ProcediaSocial and Behavioral Sciences, 112, 1056-1063.

[8] Jäger, A., Mayrhofer, W., Kuhlang, P., Matyas, K., \& Sihn, W. (2013). Total immersion: Hands and heads-on training in a learning factory for comprehensive industrial 
engineering education. The International journal of engineering education, 29(1), 23-32.

[9] Khalid, N., Hamid, N. A. A., Sailin, R., Othman, N., Awang, A. H., \& Nor, M. F. M. (2014). Importance of soft skills for industrial training program: employers' perspective. Asian Journal of Social Sciences \& Humanities, 3(4), 10-18.

[10] Matt, D. T., Rauch, E., \& Dallasega, P. (2014). Mini-factory-a learning factory concept for students and small and medium sized enterprises. Procedia CiRP, 17, 178-183.

[11] Nazron, M. A., Lim, B., \& Nga, J. L. (2017). Soft Skills Attributes and Graduate Employability: A Case in Universiti Malaysia Sabah. Malaysian Journal of Business and Economics (MJBE).

[12] Piaget, J. (1964) The Early Growth of Logic in the Child. London: Routledge and Kegan Paul.

[13] Tether, B., Mina, A., Consoli, D., \& Gagliardi, D. (2005). A Literature review on skills and innovation. How does successful innovation impact on the demand for skills and how do skills drive innovation. ESRC Centre for Research on Innovation and Competition University of Manchester, Manchester.

[14] Veza, I., Gjeldum, N., Mladineo, M., Celar, S., Peko, I., Cotic, M., \& Stojkic, Z. (2017). Development of assembly systems in lean learning factory at the University of Split. Procedia Manufacturing, 9, 49-56. 